\title{
506 円筒介在物による弾性散乱波の位相・振幅に関する理論解析
}

Theoretical analysis on amplitude change and phase shift of elastic scattering waves by cylindrical inclusions

\author{
○学 古嶋亮一（東京工業大学） 正 松尾陽太郎（東京工業大学）
}

塩田忠（東京工業大学） 正 安田公一（東京工業大学）

Ryoichi FURUHIMA, Tokyo institute of Technology, Ookayama2-12-1, Megro-ku, Tokyo Yohtaro MATSUO, Tokyo institute of Technology, Tadashi SHIOTA, Tokyo institute of Technology Kouichi YASUDA, Tokyo institute of Technology

\begin{abstract}
Changes in amplitude and phase of incident waves due to scattering by cylindrical inclusions contained in an isotropic matrix are considered. These changes relate to changes in apparent sonic velocity and attenuation coefficient obtained by the ultrasonic method. The integral equation suggested by Lavrov ${ }^{(1)}$ for scattering waves due to single inclusion gives the changes in amplitude and phase. In order to consider the cases that the number of inclusions contained in the matrix is more than two, the frequency response function corresponding to the frequency response when the incident waves passed through the single inclusion in the matrix was introduced.
\end{abstract}

1.はじめに

材料中の介在物により入射した弾性波が散乱することは 知られているが、それにより弾性波がどのように変化する かを定量的に調べた例はほとんどない。本研究では Lavrov らが報告した単一の円筒状介在物上での弾性波散乱に関す る解析方法 ${ }^{(1)}$ 用いて複数の介在物を含む材料中における 縦波弹性波の振幅および位相の変化を求め弾性波の変化を 調べた。

\section{2. 解析方法}

前提条件として、等方弾性マトリックス中に円筒介在物 が存在する系を考える。円筒介在物は長軸方向の長さが $2 \mathrm{~L} 、$ 直径 $2 \mathrm{~h}$ の等方弾性体とし、Lは $\mathrm{h}$ よりも十分大きいとする。

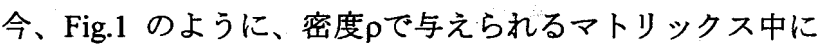
密度 $\rho_{1}$ の円筒介在物が $\mathrm{x}_{1}=0$ から $\mathrm{x}_{1}=2 \mathrm{~L}$ に存在すると仮定し、 そこに平面弾性縦波を円筒の長軸方向 $\left(\mathrm{x}_{1}\right.$ 軸) に垂直 $\left(\mathrm{x}_{3}\right.$ 軸) に入射させた系を考える。このとき入射波の変位べクトル

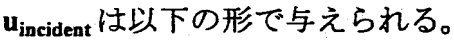

$$
u_{\text {incident }}=u_{0} \exp \left\{-i \omega\left(t-x_{3} / c_{L}\right) \cdot i_{3}\right\}
$$

$\mathrm{u}_{0}$ は入射波の平均変位（振幅）、 $\omega$ は入射波の角周波数、 $\mathrm{c}_{\mathrm{L}}$ は入射波の縦波音速、 $\mathbf{i}_{3}$ は $\mathrm{x}_{3}$ 軸方向の単位べクトルである。

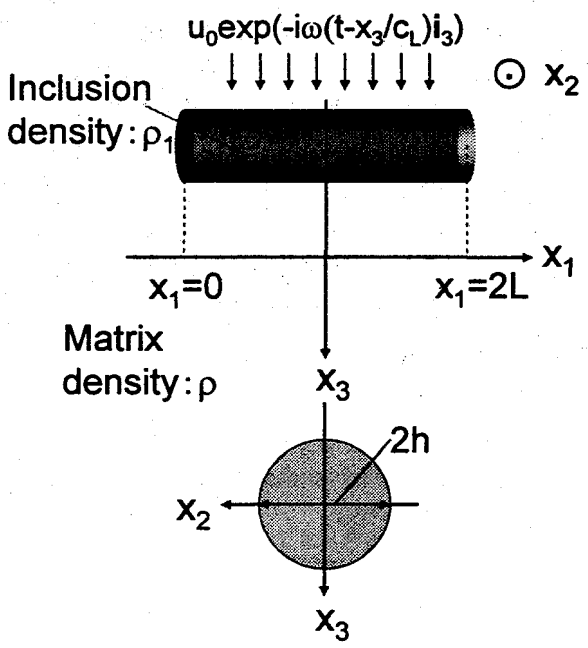

ここで円筒介在物の長さ $2 \mathrm{~L}$ を上記の式から消去するた めに、規格化を行い円筒介在物が $\mathrm{x}_{1}=-1$ から $\mathrm{x}_{1}=1$ に存在す るように変換すると、単一の円筒気孔による入射波の散乱 後の $\mathrm{x}_{1}$ 軸上の $\mathrm{x}_{1}=\mathrm{s}$ における $\mathrm{x} 1, \mathrm{x} 2, \mathrm{x} 3$ 軸方向の変位べク トルの成分を入射波の振幅 $\mathrm{u}_{0}$ で割った規格化変位 $U_{\mathrm{S} 1}\left(\mathrm{x}_{1}\right)$, $\mathrm{U}_{\mathrm{S} 2}\left(\mathrm{x}_{1}\right), \mathrm{U}_{\mathrm{S} 3}\left(\mathrm{x}_{1}\right)\left(\mathrm{x}_{1}=\mathrm{s}\right)$ は Lavrov らにより以下のように求め られている(1)。

$\mathrm{U}_{\mathrm{s} 1}(\mathrm{~s})=\mathrm{U}_{\mathrm{s} 2}(\mathrm{~s})=0$

$U_{s 3}(s)=A\left[\begin{array}{l}B U_{s 3}(s) \cdot f(s)+\int_{1}^{1} K\left(\left|s-s^{\prime}\right|\right) U_{s 3}\left(s^{\prime}\right) d s^{\prime} \\ +B\left\{\int_{-1} \frac{U_{s 3}\left(s^{\prime}\right)-U_{s 3}(s)}{\left|s-s^{\prime}\right|} d s^{\prime}\right\}\end{array}\right]+1$

$K(s)=\frac{1}{s}\left[\begin{array}{l}\exp (i p s)-\frac{3-4 v}{4(1-v)}-\frac{1}{p^{2} s^{2}} \\ \left\{\exp \left(\frac{i c_{s} p}{c_{L}} s\right) \cdot\left(\frac{i c_{s} p}{c_{L}} s-1\right)-\exp (-i p s) \cdot(-i p s-1)\right\}\end{array}\right]$

$A=\frac{-(1-q) p^{2} \varepsilon^{2}}{4} \quad B=\frac{3-4 v}{4(1-v)}$

$f(s)=2 \ln 2+\ln \left(\frac{2 s-s^{2}}{\varepsilon^{2}}\right)+\frac{4(1-v)}{3-4 v}$

ここで $\mathrm{c}_{\mathrm{s}}$ は横波の音速、 $\varepsilon=h / L 、 q=\rho_{1} / \rho 、 p=\omega L / c_{s}$ であ る。このようにして単一円筒介在物での散乱前後での変位 の変化率を解析的に求めることができ、円筒空孔による弾 性波の散乱により得られる平均変位は、入射波の伝播方向 $\mathrm{x}_{3}$ の成分のみが存在することがわかった。

(3) （6)式で表される積分方程式を数值的に解くと、規格 化変位 $U_{\mathrm{S} 3}(\mathrm{~s})$ は複素数として以下の形で得られる。

$\mathrm{U}_{\mathrm{s} 3}(\mathrm{~s})=\operatorname{Re} \mathrm{U}_{\mathrm{s} 3}(\mathrm{~s})+\operatorname{Im} \mathrm{U}_{\mathrm{s} 3}(\mathrm{~s})$

また $\mathrm{U}_{\mathrm{S3}}(\mathrm{s})$ は入射波に対する散乱波の比を意味しているの で、振幅の増幅度 R と位相の変化量 $\theta$ を用いて以下のように 表すことができる。

Fig.1 A schematic illustration of scattering system

[№.07-63] 日本機械学会第 15 回機械材料・材料加工技術講演会講演論文集 [2007-11.17,18, 長岡市] 
$U_{s 3}(s)=\frac{y(t)}{x(t)}=R \cdot \exp (i \theta)$

ここで $\mathrm{x}(\mathrm{t}), \mathrm{y}(\mathrm{t})$ はそれぞれ入射波と散乱波の変位場である。 (7)式、(8)式より $\mathrm{R}$ と $\theta$ は規格化変位 $\mathrm{U}_{\mathrm{S3}}(\mathrm{s})$ の実部と虚部を 用いて以下のように表される。

$\mathrm{R}=\sqrt{\left\{\operatorname{Re} \mathrm{U}_{\mathrm{s} 3}(\mathrm{~s})\right\}^{2}+\left\{\mathrm{ImU}_{\mathrm{s} 3}(\mathrm{~s})\right\}^{2}}$

$\theta=\tan ^{-1}\left(\frac{\operatorname{Im} U_{3}(s)}{\operatorname{Re} U_{3}(s)}\right)$

$\mathrm{R}$ および日はマトリックス中に円筒介在物が 1 つ存在す るときには数值的に求められるが、介在物が複数存在する 場合は求められない。しかしながら周波数応答および伝達 関数の概念を用いれば、簡単な系に関しては $\mathrm{R}, \theta$ を推定す ることができる。

今、Fig.2 に示すように入射の伝播方向に垂直に複数の円 筒介在物が存在する系を考える。介在物間の距離は入射波 の波長の 2 倍以上とし、散乱波の相互作用の影響は無視す る。このとき単一の円筒介在物を入射波が通過したときの 周波数応答を $F(\omega)$ 、入射波が通過する円筒介在物の個数を $\mathrm{N}$ とおくと、入射波すなわち入力波 $\mathrm{X}(\omega)$ と $\mathrm{N}$ 個の介在物に よる散乱波すなわち出力波 $\mathrm{Y}(\omega)$ の関係は周波数応答 $\mathrm{F}(\omega)$ を用いて以下のように表される。

$\mathrm{Y}(\omega)=\{\mathrm{F}(\omega)\}^{\mathrm{N}} \mathrm{X}(\omega)$

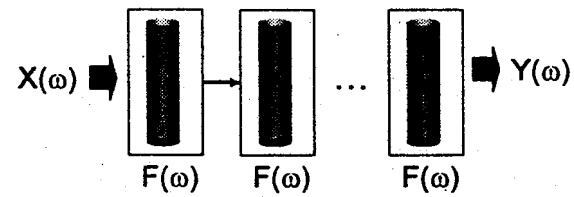

Fig.2 The system in which elastic waves propagate through a material including more than two spherical inclusions

ここで $F(\omega)$ は単一円筒介在物を通過するときの入力波と 出力波の比で表されることから、これは先に述べた規格化 変位 $\mathrm{U}_{\mathrm{S3}}(\mathrm{s})$ と等しいことがわかる。よって $\mathrm{F}(\omega)$ は振幅の増 幅度 $\mathrm{R}$ と位相の変化量 $\theta$ と関連付けることができ以下のよ うに与えられる。

$F(\omega)=\frac{Y(\omega)}{X(\omega)}=R \cdot \exp (i \theta)$

(12)式から $\mathrm{N}$ 個の円筒介在物による散乱波 $\mathrm{Y}(\omega)$ は以下のよ うに求まる。

$\mathrm{Y}(\omega)=\mathbf{R}^{\mathrm{N}} \exp (\mathrm{iN} \theta) \cdot \mathrm{X}(\omega)$

またフーリエ逆変換により角周波数 $\omega$ を引数とした入力波 $\mathrm{X}(\omega)$ 、出力波 $\mathrm{Y}(\omega)$ から以下のような時間 $\mathrm{t}$ を引数とした入 力波 $\mathrm{x}(\mathrm{t})$ 、出力波 $\mathrm{y}(\mathrm{t})$ の関係に変換できる。

$y(t)=R^{N} \exp (\mathrm{iN} \theta) \cdot x(t)$

(14)式により $\mathrm{N}$ 個の介在物による散乱波の波形の変化につ いて求めた。

\section{3. 解析結果}

Fig.3(a), (b)に $\mathrm{x}_{1}=0$ における規格化変位 $\mathrm{U}_{\mathrm{S} 3}(0)$ の振幅の増 幅度 $\mathrm{R}$ と位相変化量 $\theta$ の無次元の周波数 $\mathrm{p}$ に対する変化の計 算結果を示す。マトリックスと介在物の密度比 $\mathrm{q}$ の值によ り $\mathrm{p}$ の増加に対して $\mathrm{R}, \theta$ の増加, 減少の傾向が異なるこ

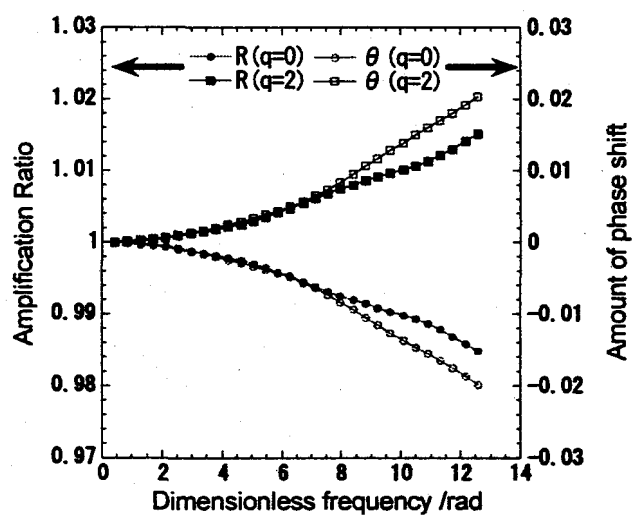

Fig.3 The effect of dimensionless frequency on $\mathrm{R}$ and $\theta$ for $\mathrm{q}=0$ and $\mathrm{q}=2$

とが見て取れる。ただし $\mathrm{R}, \theta$ 変化量はともに $\mathrm{p}$ の増加に 対して増加することがわかった。

Fig.4に密度比 $\mathrm{q}=0$ の時の異なる介在物数 $\mathrm{N}$ に対する出力 波形の変化の結果について示す。入射波の周波数は $1.4 \mathrm{MHz}$ とする。単一の介在物のみの場合 $(\mathrm{N}=1$ のとき)、出力波形 の変化はほとんど確認できないが、 $\mathrm{N}$ が増加するに従って 徐々に出力波形に変化が見られるようになる。このことか ら、円筒介在物による散乱波への影響は一つのみでは微小 であるが、多数になるとその影響が大きくなることがわか うた。

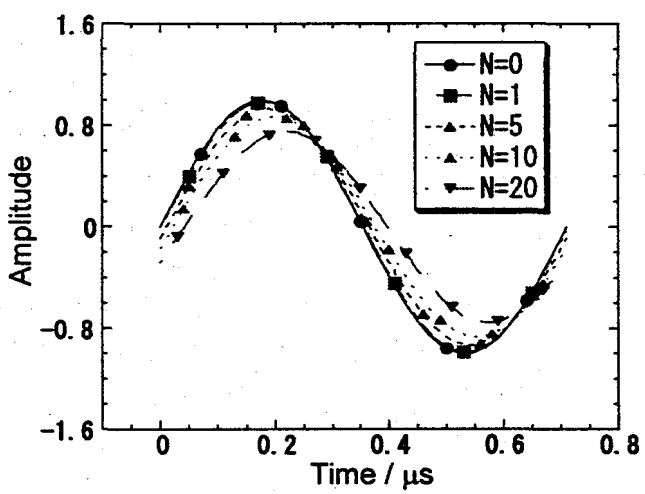

Fig.4 The effect of the number of inclusions on output waves for $q=0$

\section{4. 結論}

弾性平面入射波の円筒介在物上での散乱による振幅と位 相の変化について考察した。単一の円筒介在物による散乱 波の規格化変位を Lavrovらが提案した䅡分方程式を数值的 に解き、そこから単一の介在物による振幅の増幅度 $\mathrm{R}$ と位 相の変化量 $\theta$ を求めることが出来る。さらに入射波の単一の 介在物通過による周波数応答を求めた、この周波数応答を 複数回かけ合わせることにより複数の介在物による振幅と 位相の変化を求めた。得られた予测出力波形の結果から、 入射波が通過する円筒介在物の個数が増えるに従って、出 力波形が目に見える形で変化していくのがわかうた

\section{参考文献}

(1) N.A. Lavrov and E.E. Pavrovskaia, J. Sound and Vibration, v.248, n.2 (2001) pp.329-350 